\title{
Cognitive Load of Assigned EFL Textbooks for Al-Azhar Secondary School Students: An Analytical Study
}

\author{
Hussein Taha Atta ${ }^{1}$, Abdullah Mahmoud Ismail ${ }^{2}$, Tarek Mohammad Yussuf ${ }^{3}$ \\ ${ }^{1}$ Chair of Curriculum \& Instruction Dept., Faculty of Education, Sohag University, Sohag, Egypt. \\ ${ }^{2}$ Professor of Curricula \& EFL Methodology, Faculty of Education, Sohag University, Sohag, Egypt. \\ ${ }^{3}$ A senior teacher of English Al-Azhar Al Shareef, Sohag, Egypt.
}

DOI:

\begin{abstract}
Textbook is one of the media used in English language learning. A great number of EFL textbook evaluation have been done to find the most suitable textbook for English language teaching. The present study aimed to determine the cognitive load involved in the textbook for Al-Azhar secondary school students. Therefore, a content analysis instrument has been designed to analyze the second-year of secondary English textbook. The instrument has been distributed on the first participants in this study, (100) secondary EFL students selected out of (1143) secondary EFL students of (13) public secondary schools in Juhaina to be the purposeful sample in this study. The second participants in this study are (20) secondary EFL teachers selected out of (52) secondary English language teachers working in (13) public secondary schools in Juhaina to be the purposeful sample in this study. The results showed high levels of cognitive load in the EFL current textbook. In general, most of teachers and students think that the current EFL textbook involves high levels of cognitive load. Implications for foreign language instruction in this regard are provided.
\end{abstract}

Key words: Cognitive load, Content Analysis, Foreign English Textbook Analysis.

\section{Introduction}

Textbook is one of many materials which are most frequently used in teaching learning process. It is one of knowledge sources which is the easiest to obtain and becomes one of many aids to assist the students in acquiring clear concepts of subject matter (Rahmawati, 2018). Textbook is a book written by experienced and well-qualified people and the material contained in textbook is usually carefully tested in pilot studies in actual teaching situations before publication.
The use of textbook in teaching-learning has both advantages and disadvantages depending on how they are used and the context for their use. Since textbooks play an essential role in language classrooms in all types of educational institutions such as schools, colleges, language schools all over the world. Most of the students who use a textbook as their resource feel secure and have a sense of progress and accomplishment. Textbooks can be-a resource for independent 
learning, an effective source for introducing materials to the teachers, a source of ideas and activities, a reference source for students, a syllabus that reflects preset learning objectives, and a support for novice teachers who lack experience in selecting the efficient language materials (Alshumaimeri \& Alzyadi 2015).

One of the main factors behind retarded EFL instruction might be the cognitively overload language curricula that are incompatible with learners' processing capabilities. This cognitive load involved in educational designs threatens the educational system especially in pre-university education. It occurs because of the use of traditional educational means that pump information into the student continuously and the role of the student is only receiving and listening to information provided to him. Coding, processing and storage in working memory are effortful tasks. There is an urgent need to reduce the load of knowledge imposed on memory during learning for achieving effective learning (Abuseif 2018). Memory and brain theories help better understand communicative acts that help individuals develop automated schemas for information and enhance prior sets of automated schemas to account for more complex knowledge/information (Sexton 2017). The cognitive load theory is more likely to provide new insight in this regard.

\section{Background of the problem}

The cognitive load theory is a theory which describes the way that humans process information and learn (Jankowska 2011). " With regards to the design of instructional material, cognitive load theory suggests that several cognitive mechanisms are involved in learning and understanding instructional material. Instructional message content relevance, as a communicative act, likely has a resounding influence on learners' cognitive load (Russell 2011, p.23). The emergence of cognitive load theory can be traced back to the early steps that were taken by Mawer and Sweller in 1982 followed by a study of Sweller and Levine in 1982 through a series of experiments with the intention to explain how some forms of problem solving interfere with learning.

Sweller et al., (1998) confirmed that there are three types of cognitive load; they are intrinsic, extraneous, and germane cognitive loads. Sweller, Ayres, and Kalyuga (2011) concluded that intrinsic cognitive load is related to the material being learned. Extraneous cognitive load refers to working memory resources being devoted to elements of instruction that are unnecessary and interfere with schema activation and automation. Germane cognitive load refers to instructional manipulations that assist the learner to use working memory resources to learn a specific activity or task. Shehab (2011) confirmed that long-term memory is the main knowledge storage for new knowledge and skills, whereas working memory underlies the processing of new information. Grobe (2018) stated that information store principle is a huge long-term memory capacity to store organized 
information in the form of schemas that can be handled as a single element in working memory. Sensory memories are visual and auditory. Visual memory involves memory representations that maintain information about the perceptual characteristics of viewed stimuli, and auditory memory holds all of the auditory (non-verbal) information received from the environment. This visual processing is described as feed-forward and bottom-up, a second type of selective attention process involves actively maintaining in short-term memory a location or object as the target of attention and using this by top-down processes to influence earlier cortical processing (Al-Morsi 2018). Information from recent events lives in the temporary storage of the human brain known as working memory (Bijani 2015). Working memory can be loosely described as interrelated cognitive mechanisms that maintain newly acquired information and retrieve stored information to an active state for the purpose of further processing and manipulating. It is in working memory where complex cognitive tasks such as reasoning and problem solving occur (Baddeley 1992, 2003).

The essence of working memory is the domain general ability to focus attention, which is provided by short-term memory and supported by other domain specific knowledge bases. Gupta (2017) explained that, human working memory is rather poor and cannot typically manage more than about seven elements or chunks of information at a time and perhaps as few as three to five chunks. This limitation influences learner's performance in mental tasks. The second limitation of working memory is that information is lost if not rehearsed. (Jiang 2014). The cognitive architecture pays attention to the role of working memory (WM) in creating and storing information to be transferred to and stored in long-term memory for following use. Mikola (2010) refers to those cognitive abilities involving initiation, planning, sequencing, and regulation of behavior. WM is related to the maintenance of information in memory. It is related both to maintaining and updating information in memory. In order to manage more complex cognitive tasks, individuals must be able to access large amounts of information (Al Feel 2013).

Within long-term memory a fundamental division is drawn between declarative (i.e., conscious or explicit) and non-declarative (i.e., unconscious or implicit) forms of memory. Despite this division, a central assumption within memory theory is that unconscious memory processes influence and support conscious remembering. In particular, studies have emphasized the distinction between conceptual and perceptual memory processes. Perceptual memory depends on preliminary stages that analyze physical or sensory features of the stimuli. Conceptual memory, on the other hand, requires higher-level processing and focuses on extraction of meaning and semantic features (Vakil, Wasserman, \& Tibon, 2018). Neuroimaging studies have indicated that perceptual priming is associated with reduced activation in parts of the occipital and inferior temporal brain regions, while conceptual priming 
is associated with reduced activation in the inferior prefrontal cortex (Cabeza \& Nyberg 2000).

Most of the learned, intellectual skills that people demonstrate can be explained by using schemas. For instance, an ability to read varying text, whether it is handwritten or printed, could be explained by schemas that learners have acquired for each letter, many words and probably even many words combinations (Aslan 2014). Learning needs a change in the schematic construct of long-term memory. Schemata are cognitive constructs that allow an individual to treat multiple elements of information as a single element in terms of imposed WM load. Schemata are additionally hierarchical in nature and are usually made up of many interrelated elements, which include both the cognitive representation of the problem and the problem solution. Given that a schema can be managed in WM as a single element, increased WM can be left open to address the problem state at hand (Pociak 2004). Schema acquisition, a key component of learning, could improve performance. Cognitive load theory is mainly based on limited resource and schema theory. Schema theory then confirms the importance of a person's background knowledge through the process of text comprehension and schemata are considered as the guiding structures in the comprehension process (Best 2013).

An essential aspect of schema is the principle of automation. Automation allows for the processing of schemata in an automated fashion (i.e., as a single element or chunk), thus further reducing imposed demands on working memory. The term automation is closely related to expertise effect (Pociask 2004). Automation expertise can impact perceptions of system accuracy. Automation occurs when schemas stored in long-term memory can be processed unconsciously consequently it reduces the load on working memory. The main assumption of cognitive load theory is to reduce that load created by poor designs that reduce working memory capacity for learning (Aslan 2014). Fundamental principle of CLT is that the quality of instructional design will be greater if attention is paid to the role and limitation of working memory (Sweller 2012).

Instruction, according to cognitive load theory, depends, basic foundations. One of these is prior knowledge needed to determine the difficulty of the material learned. The study of indicated that students with prior instruction or public speaking extra-curricular experience will have higher communicative skills and lower levels of speaking anxiety (Demanet 2016; Johnson 2012). Encoding is the most important step administrated by working memory before transition to long term memory (Joh \& Plakans 2017; Dagry 2017). It is commonly observed on episodic long-term memory tasks that retrieval cues that were not also present during encoding produces worse recall compared to retrieval cues that were present during encoding (Sweller 1994; Bui 2015). Presentation can act as a leading force toward better understanding. Dalacosta and Kamariotaki (2009) confirmed that the use of animation videos positively increases the 
students' knowledge and understanding of ultimate concepts, which are normally difficult to comprehend and often cause misconceptions to them. Mokhtar (2011) confirmed that students have fun experimenting with voice, facial expressions, emotion, and gestures that make the story "just right" for telling. Boers (2017) stated that glosses or annotations that accompany text and pictures alongside textual information clarify the meaning of unfamiliar words.

Fig (1): The cognitive processing system

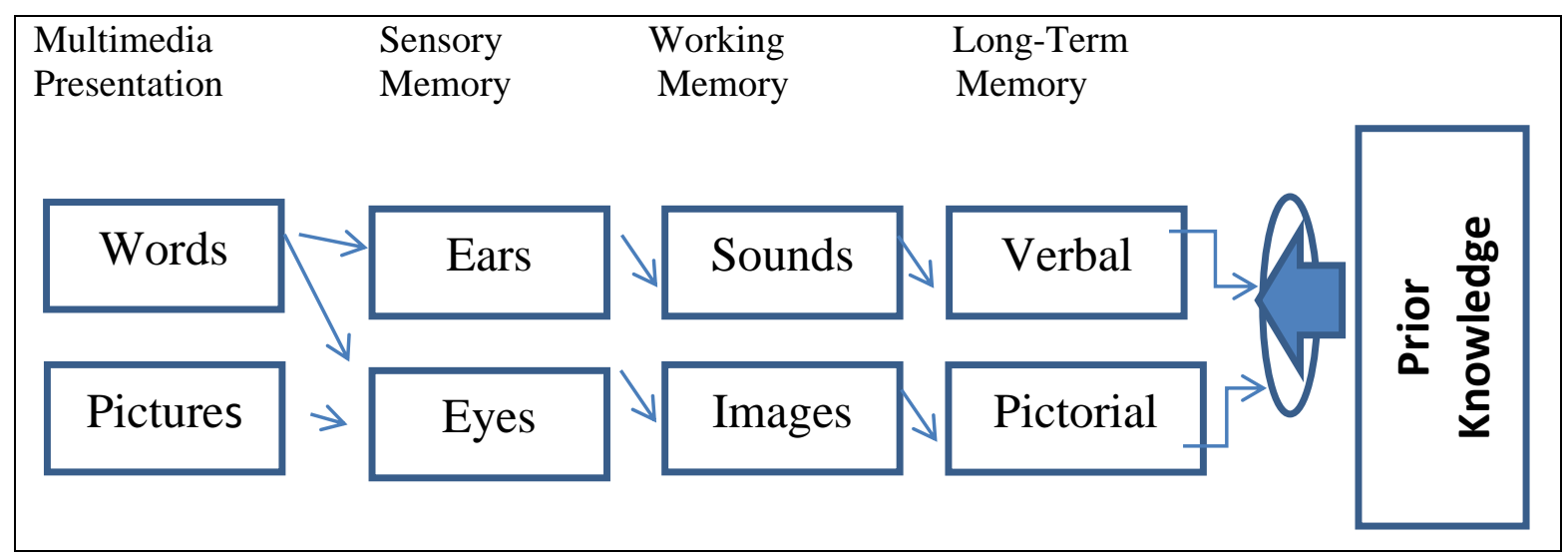

(Mayer \& Moreno 2003)

Sweller (2012) concentrated on how human mind process information and confirmed that instructional designs that do not aim to alter longterm memory and which ignore working memory limitations when processing information are unlikely to be effective. Jiang (2014) referred to cognitive load confirming that without consolidating the words from the acquainted level to the established level, students are more likely to forget the pronunciation, spelling, and meanings of those words sooner. Best (2013) assured that for effective learning to occur, schemata must be transferred successfully from working memory to long-term memory. Sweller and others (2011) confirmed that without knowledge of human cognitive processes, instructional design is blind. As complexity of the task increases, intrinsic load also increases and therefore controlling the cognitive load is important in achieving meaningful and efficient learning outcomes in the instructional environment.

Despite the importance of cognitive load theory in dealing with human mind and the essence of learning process, many instructional designs neglect this principle through constructing cognitively overloaded curricula. Learners reach a state of cognitive overload when the demands of learning exceed their existing working memory capacity. The effects of cognitive overload manifest in the learner as frustration, anxiousness or loss of confidence in one's ability to complete the course or assignment. Best (2013) confirmed that a successful training program is one that enables novices to build their own provision schemata by combining a systems approach to instruction avoiding the bad results of the ill-sequenced textbooks in EFL education. 


\section{Statement of the problem}

Dealing with the current context, the researcher noticed that EFL textbooks are redundant, illsequenced and unattractively presented which in turn may be a severe source of cognitive load and frustration to students. This belief copes with those studies about EFL textbooks both internationally and locally. International studies around the world referred to cognitive load in EFL textbooks. For example, the study of Jiang (2014) referred to cognitive load in EFL textbooks. Songdan and Feng (2015) claimed that the ideational aspect of the visual construction of knowledge and how this relates to the existing primary and secondary curricula remain unexplored or unexploited. Sterci (2016) stated that textbooks include a large number of units without tasks that support communicative language teaching.

The position of TEFL in Arab countries is extremely devastating especially in designing textbooks and topics involved. Teachers who used textbooks do not seem satisfied with them. Teachers also expressed their desire to omit, replace and add some activities to fill the persistent gap in these activities. They do not provide enough productive communicative student-centered tasks. Al Saraj (2012) stated that many conventional texts and worked examples have split-attention formats that may negatively impact learning. Meanings of new words presented in a random and isolated display are tremendously difficult. Alguthami (2016) stated that Arab EFL learners have poor performance in their EFL visual word recognition due to the lack of regularity and/or consistency that led to high levels of cognitive load.

Studies in the Egyptian context refer to similar problems regarding cognitively overloaded EFL textbooks and consequently students' inability to function properly in this regard. For example, the study of Al Zohairy (2008) referred to cognitive load and aimed to evaluate the language learning activities of Hello!6 textbooks for first year in Egyptian secondary stage that showed some types of functional communication activities were rarely found or nonexistent The study of Diab (2013) concluded that the creativity of EFL/ESL textbook was found to fail respectively. The study of El Sayed (2015) revealed that English textbooks for commercial schools contain huge amounts of cognitive load. AbdelMoneim (2019) confirmed that EFL curricula in Egypt only focus on grammatical competence rather than communicative competence, this led to apparent weakness in students' oral fluency and listening comprehension consequently high levels of mental load. In summary, it is very important for us to conduct EFL textbook evaluation so as to ensure that they can effectively facilitate the attainment of teaching objectives, and at the same time, be economically beneficial to teachers and students. Ill-designed textbooks would be likely to negatively affect both teaching and learning. Financial resources would also be wasted. 


\section{Questions of the study}

Two questions were tackled as follows:

1. What is the students' perspective about the assigned EFL textbook?

2. What is the teachers' perspective about the assigned EFL textbook?

\section{Design of the study}

To achieve the aim of this study, the researcher adopted the analytical approach. Such an adoption was due to the nature of the research, which aimed at discussing and analyzing the nature of the assigned EFL textbooks and the opinions of students and teachers about them. According to Sandelowski (2000), descriptive method not only describes a certain phenomenon but also collects, arranges and categorizes the data about this phenomenon quantitatively that leads to a better understanding of the relationships between this phenomenon and other phenomena. Arranging and categorizing collected data aim to reach certain conclusions that help in developing the reality that the researcher studies.

\section{Population \& Participants}

Since content analysis is the selected tool for this research, English textbook (level 11) that is taught in public schools in Al-Azhar secondary schools, represents the first population of this research and all the unites of this textbook represent the participants of this research. Therefore, the participants in this study are (100) secondary EFL students selected out of (1143) secondary EFL students of (13) public secondary school in Juhaina to be the purposeful sample in this study. This number is estimated by the data collection center in the Juhaina administration. So, the population of this study is well represented by the selected participants. The second participants in this study are (20) secondary EFL teachers selected out of (52) secondary English language teachers working in (13) public Secondary school in Juhaina to be the purposeful sample in this study. This number is estimated by the data collection center in the Juhaina administration. So, the population of this study is well represented by the selected participants.

\section{Data Collection}

To decide on the current context, the researcher conducted a content analysis of the English textbook for second year secondary school students. The content analysis aimed at measuring the cognitive load involved in the assigned English textbook as well as the employed activities and instructional procedures. The researcher adopted NASA TLX (Hart \& Staveland 1988). The questionnaire was employed in the study as a quantitative method for collecting objective data from some EFL teachers and students. The NASA Task Load Index is a widely used as a multidimensional assessment tool that rates perceived workload in order to assess a task, system, or team's effectiveness or other aspects of performance. It has been used in a variety of domains, 
including aviation, healthcare and other complex socio-technical domains. The designed content analysis instrument has collected the necessitated data to shape a complete background about the topic and to investigate students' as well as teachers' perceptions of cognitive load of the assigned language textbook.

This instrument consists of thirty items of six major dimensions which are mental, physical, temporal, performance, effort and frustration loads. The mental dimension includes items (1, 2, 3, 4, 5). Physical dimensions include $(6,7,8,9$, 10). Temporal dimension includes items $(11,12$, 13, 14, 15). Performance dimension includes items $(16,17,18,19,20)$. Effort dimension includes items $(21,22,23,24,25)$. Finally, frustration dimension includes items $(26,27,28$, $29,30)$.

NASA TLX questionnaire

\begin{tabular}{|c|c|c|c|c|c|c|}
\hline جै & Items & 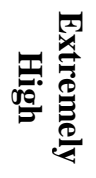 & 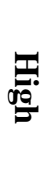 & 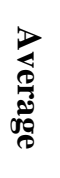 & $\sum_{z}$ & 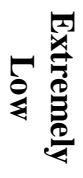 \\
\hline \multirow{4}{*}{$\stackrel{3}{\stackrel{3}{9}}$} & $\begin{array}{l}\text { 1. The content involves perceptual activities. } \\
\text { 2. The content involves remembering activities. }\end{array}$ & & & & & \\
\hline & 3. The content involves searching activities. & & & & & \\
\hline & 4. The content involves comparing activities. & & & & & \\
\hline & 5. The content involves analyzing activities. & & & & & \\
\hline \multirow{4}{*}{ 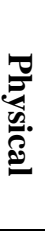 } & 6. The content involves eye-strain causing activities. & & & & & \\
\hline & 7. The content involves headache causing activities. & & & & & \\
\hline & 8. The content involves backache causing activities. & & & & & \\
\hline & $\begin{array}{l}\text { 9. The content involves repeated painful activities. } \\
\text { 10. The content involves pushing/pulling activities. }\end{array}$ & & & & & \\
\hline \multirow{5}{*}{ 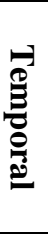 } & 11. The content involves time pressure activities. & & & & & \\
\hline & 12. The content involves idle time activities. & & & & & \\
\hline & 13. The content involves synchronous activities. & & & & & \\
\hline & 14. The content involves interrupted time activities. & & & & & \\
\hline & 15. The content involves extended time activities. & & & & & \\
\hline \multirow{4}{*}{ 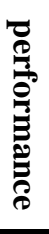 } & $\begin{array}{l}\text { 16. The content involves needed guidance activities. } \\
\text { 17. The content involves expertise learning activities. }\end{array}$ & & & & & \\
\hline & 18. The content involves typical activities. & & & & & \\
\hline & 19. The content involves means-end activities. & & & & & \\
\hline & 20. The content involves explanation activities. & & & & & \\
\hline \multirow{4}{*}{ 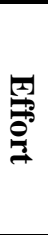 } & 21. The content involves laborious activities. & & & & & \\
\hline & 22. The content involves strenuous activities. & & & & & \\
\hline & 23. The content involves brisk activities. & & & & & \\
\hline & $\begin{array}{l}\text { 24. The content involves painful positions activities. } \\
\text { 25. The content involves controlling activities. }\end{array}$ & & & & & \\
\hline \multirow{5}{*}{ 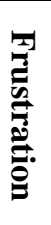 } & 26. The content involves insecure activities. & & & & & \\
\hline & 27. The content involves discouraged activities. & & & & & \\
\hline & 28. The content involves stressed activities. & & & & & \\
\hline & 29. The content involves annoying activities. & & & & & \\
\hline & 30. The content involves irritating activities. & & & & & \\
\hline
\end{tabular}

The questionnaire was translated in Arabic then presented to students. The following table summarizes the basic findings of the questionnaire. 
Table (1): Students' perceptions about the cognitive load in assigned textbooks

\begin{tabular}{|c|c|c|c|c|}
\hline & Variables & Frequency & Percentage & Cumulative percent \\
\hline \multirow{5}{*}{ 光 } & Extremely Low & 2 & 2.0 & \multirow{2}{*}{5.0} \\
\hline & Low & 3 & 3.0 & \\
\hline & Average & 10 & 10.0 & 15.0 \\
\hline & High & 51 & 51.0 & \multirow{2}{*}{85.0} \\
\hline & Extremely High & 34 & 34.0 & \\
\hline \multirow{5}{*}{ 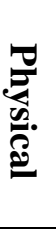 } & Extremely Low & 3 & 3.0 & \multirow{2}{*}{7.0} \\
\hline & Low & 4 & 4.0 & \\
\hline & Average & 18 & 18.0 & 18.0 \\
\hline & High & 69 & 69.0 & \multirow{2}{*}{75.0} \\
\hline & Extremely High & 6 & 6.0 & \\
\hline \multirow{5}{*}{$\begin{array}{l}\overrightarrow{0} \\
\stackrel{3}{0} \\
0 \\
0 \\
0\end{array}$} & Extremely Low & 3 & 3.0 & \multirow{2}{*}{8.0} \\
\hline & Low & 5 & 5.0 & \\
\hline & Average & 9 & 9.0 & 9.0 \\
\hline & High & 53 & 53.0 & \multirow{2}{*}{83.0} \\
\hline & Extremely High & 30 & 30.0 & \\
\hline \multirow{5}{*}{$\begin{array}{l}\overrightarrow{0} \\
\stackrel{0}{0} \\
\stackrel{0}{0} \\
\stackrel{0}{3}\end{array}$} & Extremely Low & 1 & 1.0 & \multirow{2}{*}{4.0} \\
\hline & Low & 3 & 3.0 & \\
\hline & Average & 5 & 5.0 & 9.0 \\
\hline & High & 77 & 77.0 & 860 \\
\hline & Extremely High & 14 & 14.0 & 0.0 \\
\hline \multirow{5}{*}{$\begin{array}{l}\stackrel{2}{\overrightarrow{0}} \\
\stackrel{0}{2}\end{array}$} & Extremely Low & 2 & 2.0 & \multirow{2}{*}{4.0} \\
\hline & Low & 2 & 2.0 & \\
\hline & Average & 4 & 4.0 & 8.0 \\
\hline & High & 56 & 56.0 & \multirow{2}{*}{92.0} \\
\hline & Extremely High & 36 & 36.0 & \\
\hline \multirow{5}{*}{ 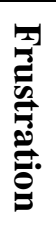 } & Extremely Low & 3 & 3.0 & \multirow{2}{*}{6.0} \\
\hline & Low & 3 & 3.0 & \\
\hline & Average & 7 & 7.0 & 7.0 \\
\hline & High & 59 & 59.0 & \multirow{2}{*}{87.0} \\
\hline & Extremely High & 28 & 28.0 & \\
\hline
\end{tabular}

It is clearly manifested that the majority of students confessed the presence of the cognitive load in assigned language textbooks. Eighty-five percent hundred think that their English textbook cause high mental load. Eighty-three think that their textbook involves temporal load. Eighty-six of the students think that their EFL textbook involves performance load activities. Seventyfive think that the textbook involves physical load. Eighty-seven think that the textbook activities require high effort. Ninety-two percent hundred felt frustration through studying the current textbook.

The results in table (2) refer to high levels of cognitive load in the EFL current textbook. Eighty-five percent hundred think that EFL textbook involves performance load. Eighty percent hundred think that English textbook causes effort load. Seventy percent hundred thinks that the EFL textbook involves mental load. Seventy-five percent hundred see that the assigned textbook causes temporal load and 
frustration to students, Sixty percent hundred think that textbook involves physical load. In general, most of teachers and students think that the current EFL textbook involves high levels of cognitive load.

Table (2): Teachers' perceptions about the mental load of assigned EFL textbook

\begin{tabular}{|c|c|c|c|c|}
\hline & Variables & Frequency & Percentage & Cumulative percent \\
\hline \multirow{5}{*}{ 光 } & Extremely Low & 0 & 0.0 & \multirow[b]{2}{*}{10.0} \\
\hline & Low & 2 & 5.0 & \\
\hline & Average & 4 & 20.0 & 20.0 \\
\hline & High & 8 & 40.0 & \\
\hline & Extremely High & 6 & 30.0 & 70.0 \\
\hline \multirow{5}{*}{ 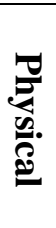 } & Extremely Low & 1 & 5.0 & \multirow{2}{*}{10.0} \\
\hline & Low & 1 & 5.0 & \\
\hline & Average & 6 & 30.0 & 30.0 \\
\hline & High & 12 & 60.0 & \multirow{2}{*}{60.0} \\
\hline & Extremely High & 2 & 10.0 & \\
\hline \multirow{5}{*}{ 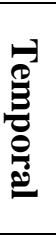 } & Extremely Low & 1 & 5.0 & \multirow{2}{*}{10.0} \\
\hline & Low & 1 & 5.0 & \\
\hline & Average & 3 & 15.0 & 15.0 \\
\hline & High & 12 & 60.0 & \multirow{2}{*}{75.0} \\
\hline & Extremely High & 3 & 15.0 & \\
\hline \multirow{5}{*}{ 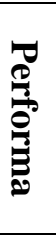 } & Extremely Low & 0 & 0.0 & \multirow{2}{*}{00.0} \\
\hline & Low & 0 & 0.0 & \\
\hline & Average & 3 & 15.0 & 15.0 \\
\hline & High & 12 & 60.0 & 850 \\
\hline & Extremely High & 5 & 25.0 & 85.0 \\
\hline \multirow{5}{*}{ 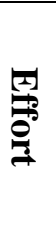 } & Extremely Low & 0 & 0.0 & \multirow{2}{*}{5.0} \\
\hline & Low & 1 & 5.0 & \\
\hline & Average & 3 & 15.0 & 15.0 \\
\hline & High & 12 & 60.0 & \multirow{2}{*}{80.0} \\
\hline & Extremely High & 4 & 20.0 & \\
\hline \multirow{5}{*}{ 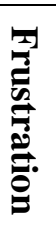 } & Extremely Low & 1 & 5.0 & \multirow{2}{*}{10.0} \\
\hline & Low & 1 & 5.0 & \\
\hline & Average & 3 & 15.0 & 15.0 \\
\hline & High & 12 & 60.0 & \multirow{2}{*}{75.0} \\
\hline & Extremely High & 3 & 15.0 & \\
\hline
\end{tabular}

The researcher then held an interview with EFL teachers and students as a qualitative research method that relies on the interaction between the researcher and the participants of the study. Thus, EFL teachers and students were asked about their perceptions, opinions, beliefs, and attitudes towards their assigned EFL textbook. Questions were asked in an interactive group setting where participants were free to talk with other group members. Questions aimed at identifying the cognitive load in the second semester units of English students` textbook and involved activities designed for developing EFL communicative competence. The analysis sample included the sub-skills' activities and procedures of these domains for communicative competence in the 
second semester of the school year. It included all the lessons in the second semester of year 2020.

Students concluded that the textbook cause cognitive load for various reasons; textbook doesn't provide a full complete material to be studied. Students cannot use the book without the aid of the teacher. The topics of the book are so separated, repeated and randomly organized.

Textbook units don't constitute a complete vision of any topic or any field of life. For grammar, there aren't explaining rules into the unit to be followed; grammar is not gradually presented from simple to complex, it is randomly presented. No suitable worked examples for rules are provided; they don't lead to transfer, through automation. Most of the visual effects don't suit the main topic of the unit causing split-attention.

Questions of the interview with EFL students and teachers

\begin{tabular}{|c|c|}
\hline No & Questions \\
\hline 1. & Is each learning task aligned with the aims of the curriculum? \\
\hline 2. & Is each task applicable in life outside the school walls? \\
\hline 3. & Is the content derived from students' cultural background? \\
\hline 4. & Is the content related to the previous studied topics or their prior knowledge? \\
\hline 5. & Does the content have continuity, unity and coherence? \\
\hline 6. & Does each task meet students' needs? \\
\hline 7. & Is the time provided suitable for the assigned tasks? \\
\hline 8. & Is higher-order thinking skill involved in each task? \\
\hline 9. & Does the content integrate language skills in a natural way? \\
\hline 10. & Does the content involve physical activities beyond the classroom? \\
\hline 11. & $\begin{array}{l}\text { Does the content involve works of literature that address local environmental issues (e.g., short } \\
\text { stories, poems, etc.)? }\end{array}$ \\
\hline 12. & Does the content involve visualization and association? \\
\hline 13. & Is the visualization suitable and supportive for the task? \\
\hline 14. & Does the content discuss important social and environmental problems? \\
\hline 15. & Does the each task provide free-goal problem solving or closed end questions? \\
\hline 16. & Does the content involve a variety of problem types? \\
\hline 17. & Does the content include independent and collaborative tasks? \\
\hline 18. & $\begin{array}{l}\text { Does the content involve information in a variety of forms, including graphics, images, audios and } \\
\text { videos? }\end{array}$ \\
\hline 19. & Does the content reflect the values of the society? \\
\hline 20. & Does the content deal with language for specific purpose? \\
\hline 21. & Does the curricular content help students to become independent? \\
\hline 22. & Does the curricular content help students to become collaborative? \\
\hline 23. & Does the curricular content develop students' oral communication skill? \\
\hline 24. & Does the curricular content enhance students' critical thinking skills? \\
\hline 25. & Does the curricular content enhanced students' creative thinking skills? \\
\hline 26. & $\begin{array}{l}\text { Does the curricular content develop students' use of vocabulary \& grammar inside and outside the } \\
\text { school walls? }\end{array}$ \\
\hline 27. & Does the curricular content develop desirable dispositions in students? \\
\hline 28. & Does the curricular content connect students to life beyond the classroom walls? \\
\hline 29. & Does the curricular content engage students in serving the surrounding community? \\
\hline 30. & Does the curricular content have an appeal to students? \\
\hline
\end{tabular}


On the other hand, teachers confirmed that some visual effects are old fashioned; others are so crowded with excessive details. There are no visual effects for words that are far away from students' realization like old-fashioned tools or scientific equipment. Sometimes they are not positioned in the exact suitable place to promote ideas and enhance learning. Most of the teachers confirmed that the textbook has some weaknesses which sometimes make difficulties for the students and teachers in teaching-learning process. First, a textbook is designed as the sole source of information which makes the students only see one perspective on a concept or issue. Second, textbook is old and outdated. This condition makes the information is not relevant. Textbook questions tend to be difficult requiring just memorization. This situation makes the students assume that learning is simply a collection of facts and figures. Fourth, textbook does not take student's background knowledge into account and makes the teacher does not tailor lessons to the specific attributes and interests of students. Fifth, the reading level of the textbook is too difficult so the student cannot read or understand important concepts which contained in the reading text.

Teachers concluded their view indicating to the disadvantages of textbooks as they are not successful to present valid and realistic language models, moreover they decrease learner roles in classroom procedures, EFL textbooks content don't have proper contextualization either through topics involved or language activities.
Besides, they provide inappropriate cultural understanding for the students; they are unsuccessful to provide discourse ability, they fail to present idioms and equity in gender representation. There is not a suitable textbook for the students with different needs. There is no a good textbook with good topics which can be relevant for and interesting to all; moreover a textbook prevents teachers' creativity. Textbooks provide their own principle, and they may not be suitable for the level of the students in class. Teachers are the slave of the book and they are not free to regard the suitable teaching methods based on students' level.

Teachers reported many difficulties with teaching this curriculum. In particular, they noticed that some sections were too difficult and advanced for students, especially the 'Islamic section'. Moreover, the textbook does not adequately reflect the real Egyptian culture. For example, there is a wide gap between the advanced content of the textbooks on one hand, and the poor conditions of many deprived local communities in the study setting, especially in rural areas. Thus, the actual local context and the specific national culture are not highly considered. Further, from a curriculum design perspective, in order for any language course to be strong and effective, the most important is that learners should feel that they have benefited from the lesson and they can use the studied material straight away (Association and Application). 


\section{Discussion}

Students confirmed that some topics, words and phrases are not culturally appropriate to learners because they are too difficult, closely connected with the English context only or so informal/colloquial; moreover, some teachers have the same feeling about the curriculum. One of them said "The curriculum is not suitable, it should be related to the Egyptian environment in villages, cities and deserted areas...There should be various teaching aids to be used by the teacher during the lesson. Another teacher discussed the temporal load involved in the assigned textbook saying "...The curriculum is long and needs much time...8 units a term. I suggest 8 units a school year...This enables the teacher to teach perfectly and also give the students the time to practise what they learn" this is aligned with the study of Abdallah (2016) which evaluated EFL textbook series at Egyptian primary schools. The study confirmed that the whole series has many vocabulary-related issues which interfere with acquiring Standard English (e.g., many words are purely American and colloquial). There are many cultural issues that make the series incompatible with the national Egyptian context.

Both students and teachers agreed that there are no suitable direct tasks provided to promote the example or enhance the skill. These tests often focus students' learning merely on memorizing information to achieve high exam scores. The dominant test-orientation in the system forms a major impairment to school and pedagogical improvements as it strengthens 'teach to the test' practices. Sometimes the textbook activities are not adequate to students' ages and developmental stage which cause the expertise reversal effect as Sweller (2012) confirmed that the expertise reversal effect occurs when information beneficial to novice learners becomes redundant to those more knowledgeable. Detailed textual explanations, especially if they are embedded into diagrams, may be essential for novices but redundant for experts. Instruction that is optimal for novices may hinder the performance of more experienced learners. Scholars need to tailor instructional methods to levels of learner expertise as it changes during learning (Spain 2009).

The textbook places much physical loads on learners. Students study three books instead of the one comprehensive textbook. Moreover the reading passages are so long and small-font written that causes a severe eye-strain to students and teachers as well. Students and teachers discuss the physical load of having three books for the same subject. One of the teachers said, "I also suggest that the English subject should be in one book, including reading and activity". In addition, most of teachers and students revealed that Visuals are randomly positioned. Sometimes they are not suitable or have a wrong position to clarify the text or promote learning process; alternatively, they cause mental and physical loads as well. Learning from spatially separated text and pictures is improved when learners are 
instructed to use a physical or mental integration strategy. This agreed with the study of de Koning, Rop \& Paas (2020) which investigated whether varying the spatial distance between text and pictures affects the effectiveness of physical and mental integration strategies. Results indicated that larger spatial distance would increase cognitive load and harm learning.

Physical load came to be clear from the results of the questionnaire applied on students and teachers as well; sixty percent hundred of teachers and seventy five percent hundred of students confirmed that the assigned curriculum includes physical overload. Through the interview, both students and teachers confirmed that the writing font and style are not appropriate that cause eye-strain and headache. "During reading, re-fixating a word could indicate that the reader is uncertain about the semantics of the current sentence and needs to return to a previously read word to comprehend the sentence, and therefore yield valuable information about a user's cognitive processes. During these saccades and fixations, the pupil dilates and contracts as a physiological response. Emotional and cognitive events along with other factors from the environment such as brightness can cause the pupil to constrict or expand. Carefully observing these meaningful signals is crucial for research in HCI as an indicator of cognitive load" (Attar 2016).

Most of students thought that the assigned curriculum requires great effort; their teachers don't do the required effort for accomplishing their mission. One of students said "Many teachers do not exert the needed effort to reach more learners (especially low achievers) and depend on memorization. Cognitive load can be defined as the amount of mental effort that performing a specific task imposes on a learner's cognitive system. It can be measured by the number of new concepts embedded in a learning task. This copes with the study of Lin \& Chen (2006) which evaluated decreasing cognitive load for novice EFL learners through descriptive advance organizers in facilitating EFL learners' comprehension. The study revealed that (EFL) learners, with their limited English proficiency and minimal entry knowledge of a subject matter, always find it effortful and or overwhelming to comprehend a content lesson delivered in English.

Teachers confirmed that the assigned textbook is associated with the high level of task-load performanc. Consequently, a higher level of cognitive load in EFL context leads to a lower level of foreign language performance. In addition, they think that foreign language anxiety is significantly but negatively associated with individual task performance. One of the interviewed teachers about the assigned EFL textbook said, "Related cultural context serves as a condition in achieving a high level of individual task performance despite the presence of a high level of foreign language anxiety". This is aligned with the study of Presbitero (2020) which affirmed that a high level of related cultural context can 
interact with foreign language anxiety, and in the process, reduce the negative effects of foreign language anxiety on individual task performance.

Activities and tasks included in the textbook causes frustration; they are not always consistent with the exam paper such as puzzles and missed letters. They are different from questions found in model tests or exercises that train them on the final exam. Moreover, there are no ideal practical applications for the Phonetics; this might cause confusion and frustration to learners especially there are no phonetic questions in the exam paper. Besides, there are no oral tests around the school year. The assigned curriculum - in general - causes frustration because it does not draw on learners' realistic hobbies, tendencies and attitudes. Some topics are not consistent with the Egyptian socio-cultural context. Students concluded that one of the most important reasons for their frustration is their inability to speak English. One of the frustrated students said "Textbooks do not focus on modeling students' pronunciation or devote some time to allow for more elaboration and practice. In this regard, an in-service teacher commented: "It's a hard and bad curriculum!" Well, it's not so bad, but the exam questioning types focus on 'memorization' except for the dialogue completion question. Usually, teachers don't give due time to the phonics section. Also, the lesson structure starts as a mechanical drill for the new vocabulary.

On the other extreme, some few teachers were against teaching the Islamic Selections content in English altogether as it includes advanced and too difficult language; it is too demanding and exhausting to both teachers and learners; and imposes much cognitive load on learners. In this regard, a teacher stated: I think it is not suitable for our students; it is complex and has difficult words for learners. The book needs to be revised so as to be more suitable. This copes with the study of Abdallah (2016) confirmed that there are many ways to improve the cognitively overload for the assigned EFL curriculum. This includes encouraging students to interact with English in classroom, using ELL sources (e.g., cartoons, films, videos, and programmes), as this would be very essential for language acquisition; and using active learning strategies and video resources to make learning more interesting and fun.

The cognitive load found in the Egyptian EFL textbook and that involved in strategies and activities serving content led to difficulties in EFL communicative competence and speaking anxiety. Students always complain of being unable to express themselves in English when they are asked to do so. At the same time, their listening comprehension is poor; when they listen to English, they find it difficult for them to understand and identify where a spoken sentence starts and where it ends. They 
are always shy, stressed, anxious, and unable to speak or compete. Despite the important role that content plays in achieving the aims of any curriculum, this content lacks social utility and relevance to Egyptian students' needs to be far away from their cultural background creating a great gap between the content being learned and their prior knowledge and schemas in students' long-term memory. This copes with the study of ElKoumy (2019) that aimed to make a content analysis for EFL curriculum in Egypt to prepare students for a $21^{\text {st }}$ century.

More than that, the textbook leads to frustration that produces desperate graduators and poor creators. Moreover, it cultivates unwanted dispositions in students to paralyze them to face the challenges of today's world and to guide their applications of the twentyfirst century skills. This is aligned with the study of Binkley et al. (2012) which confirmed that twenty-first century has witnessed accelerating change in the global economy with a direct impact on the global marketplace. As a result, employers are seeking out new skills among graduates, such as creativity, critical thinking, problemsolving, learning to learn, collaboration and information literacy skills.

Similarly, the assigned textbook involves only closed-end questions - free from open-ended local issues that prompt group discussionscausing cognitively overload content. High goal specificity leads to low schema acquisition or rule induction (Wirth, Künsting \& Leutner 2009). Goal-free problems result when a convenient problem with a specific goal is replaced by a problem with a nonspecific goal. For example, a typical problem will ask students to calculate a specific angle, such as angle ABC. However, goal-free problems will not oblige students to specifically calculate this angle but use a more general wording such as "calculate the value of as many angles as possible (Sweller et al., 2011). High goal specificity involved in textbook activities cultivates effort and temporal overload. This copes with the study of Woolley, Huang \& Rabinowitz (2019) that overstressed the effects of knowledge strategies on problem solving.

In addition, the textbook content and the serving activities are all associated with a propitious command of vocabulary, and the proficiency level of vocabulary determines the practical ability of applying the language skills in EFL contexts. No matter how proficient a learner is in grammar or phonology causing excessive mentally overload learning. This copes with the study of Teng (2015) which confirmed that EFL textbooks involve mental load in translation tasks and EFL vocabulary learning. The study also confirmed that tasks with higher degrees of need in daily life are more effective for incidental word learning. This also agreed with the study of Sweller (1994) which confirmed that mental processing must go 
through three stages: encoding, which involves processing of visual or auditory information; central processing, in which the codes are then processed; and responding, which requires a verbal or behavioral response. A more demanding task will require greater cognitive resources, causing increased interference with the concurrent task. If two tasks utilize different resources, it is argued that people should be better able to perform each task, since they require different demands for information processing.

The assigned textbook requires teachers to pour obsolete pieces of information into students' heads. They also have to devote much time and effort to teaching to tests that measure the recall of these pieces of information. This in turn leads to the graduation of students who possess an enormous amount of fragmented information, but they cannot communicate fluently or think deeply to solve the problems they face in everyday life. Nor can they work independently or collaboratively to achieve goals. This is totally contradictory with the fundamental instructional design for cognitive load theory that encourages guidance fading effect and increases expertise effect. The lack of these expertise skills in the assigned students resentfully impacts their success in life and negatively impacts the development of society in all areas of life. This is aligned with the study of Namaziandost, Hosseini \& Utomo (2020) which confirmed the same notion and recommended that textbook designers and (EFL) instructors have to design effective activities with proper difficulty levels. This copes with the study of Abdallah (2016) which analyzed the content 'Time for English' Textbook Series at Egyptian primary schools. The study indicated inadequate level association and application. The content failed to relate between what is being learned and their cultural backgrounds.

The assigned EFL textbook fails to develop students' critical thinking or explanationimagination effect. Activities and procedures serving the assigned content do not allow students to think critically or to express points of view to the classroom. Another reason is that teachers think of English language as a fixed set of grammar despite the fact that English native speakers do not speak perfectly grammatically correct English except in formal settings. This copes with the study of El-Koumy (2019) which confirmed that the failure of developing critical thinking skills in Egyptian students is attributable to a multitude of reasons. The most important is that Egyptian teachers-obtained by the Egyptian EFL students' book and directed by the teacher's guide- use a teaching method that does not allow students to think critically or to bring alternative points of view to the classroom. It also agreed with the study of Sweller et al. (2011) which confirmed that imagination effect originates when imagining a procedure or concept that makes more 
effective learning than studying the same procedure or concept. The imagination technique is a strategy depends on asking students to imagine a concept or procedure instead of taking worked examples. It occurs through providing pictures or diagrams of the basic concept then students are asked to turn away and try to imagine the steps involved in the procedure.

Similarly, the assigned EFL textbook doesn't promote learning through visualization. It is assumed that a text with visual elements is far better comprehended in comparison with a text devoid of any visual elements (Ametller \& Pinto 2002). Visuals can be effective if certain conditions are existent. For instance, if they are used appropriately with written texts, and there exists a match between the pictures and the purpose for which they are utilized, they can be effective. When used inappropriately, visuals can have adverse rather than facilitative effects, that is, they can lead to cognitive load on EFL acquisition. This copes with the study of Roohani and Sharifi (2015) that evaluated visual elements in two EFL textbooks and confirmed that pictures used for decorative purposes that constitute illustrations in textbooks have pedagogically facilitative effects.

\section{Implications}

\section{A. Implications for EFL teachers}

Teachers should be aware of the importance of the strategies based on the cognitive load theory in developing students' communicative competence skills as the traditional methods are less effective. Teachers should monitor their students' level of attention, meet needs of diverse learners, and manage internal and external distractions. Teachers have to be aware of cognitive resources imposed in lesson plans during student teaching. Cognitive overload limits the ability to make modifications during teaching.

Teachers should dominate the basic principles and strategies of cognitive load theory. Managing intrinsic load requires recolonizing and application to the serving strategies such as simple-to-complex strategy. That means to precede from low- to high- complexity tasks. To set up the procedures in a logical order for a trainee who is completing a procedure for the first time or to proceed from low- to high-fidelity environments that to practice a procedure with a trainee in a simulated setting before he/she performs the technique. Moreover, decreasing extraneous load requires worked examples that mean providing learners with problems of worked solutions.

Teachers have to be aware of the types of memory and how to deal with each type. Memory is the superior intellectual cognitive process that defines the mental organization. It is the ability to encode, store, retain, and then recall information and past experiences. Teachers have to know the role of memory in learning. Teachers should know about the 
modality effect and how to positively benefit from. They have to decrease the split attention effect by removing reasons and adopting new strategies in order to attract attention.

Teachers need to know about content analysis. Modify and develop according to the students' abilities and the nature of the subject. Content analysis can be both quantitative and qualitative. In both types, Teachers can categorize words, themes, and concepts within the texts and then analyze the results. Content analysis has various possible goals such as finding correlations and patterns in how concepts are communicated, understanding the intentions of an individual or group, and analyzing the consequences of communication content, such as the flow of information or students' responses. The textbooks have to be analyzed by using criteria of good English experts according to cognitive load theory.

Teachers should know how to make cognitive maps for the topics of the content. Mental models and cognitive maps have been used in education as an instructional design technique, assessment tool, and learning strategy. The use of mental models and cognitive maps is a device to elicit students' challenges in learning the domain knowledge of a course. Such usage is illustrated in a management information systems course. This studentfocused approach can help instructor to better understand students' learning challenges and enhance teaching effectiveness.
Teachers have to read and cope with the new modern theories of education. Education has always been awash with new ideas about learning and teaching. Teachers should be permanent callers for reform. They need to use new curricula, new teaching strategies, and new assessments. They should prepare students for the new state standardized test or to document and assess students' work through portfolios and performance assessments. They have to use research-based methods to teach and create well educated generations.

Emotional and cognitive concepts while performing in high pressured situations within the classroom environment were identified as organizational factors overloading cognitive processes, thereby negatively affecting their performance. Teachers have to provide an ease emotional and motivational environment within the classroom environment.

\section{B. Implications for textbook and program designers}

Strategies based on the cognitive load theory must be used in the teaching process as they increase the students' motivation to learn through the different techniques and tasks. Cognitive psychology has to influence the types of goals and objectives that are developed as a result of task analysis. Strategies for helping students build good mental models of problems to be solved. To promote the use of these mental models, designers should present problems in visual 
rather than written formats. Visual formats allow students to develop their own pattern recognition skills, and they are dynamic, rich, and spatial. The use of visual formats may be particularly important for low-achieving students or who have difficulty learning.

Textbook designers have to be aware of the fundamental principles of cognitive load theory. One of these is the prior knowledge availability (prerequisite). A prerequisite is something a person must know or be able to do before they are able to learn something else. To determine prerequisite information, an analysis must be done from the learner's (novice's) perspective, rather than the expert's perspective. An expert tends to overlook some of the things they needed to know in order to achieve the learning goal. Determining prerequisite skills does not specify instructional strategies. An analysis for prerequisites can be used for a top-down, problem-based environment as well as a bottom-up structured instructional strategy.

Strategies based on the cognitive load theory reduce the feeling of isolation among students, as there will be a group work during the sessions. This will also help maintain motivation at a higher level as they must continue to work together toward achieving a common goal. Using computers and internet enables students to reduce their anxiety towards learning in general and speaking in particular, moreover it creates a case of joy and fun in classroom setting.
Curriculum designers must consider the nature of the cognitive load theory and provide the curriculum with models of good techniques and activities to participate orally through the activities. These strategies based on the cognitive load theory provide students with immediate feedback from the teacher and different types of reinforcement directly and indirectly. Consequently, educational institutions should modernize their technical instruction capabilities by using new equipment and laboratories for supporting the teaching process.

\section{Limitations of the study}

Certain limitations are anticipated in this study that may affect its credibility and the quality of the achieved results accordingly. These limitations are:

1- The collected responses from the participants in the analysis process can be subjective and may not represent the real perception of the teachers towards the used materials in the selected textbook.

2- To confirm that the collected data represents the perceptions of the majority of EFL teachers all over Egypt, a lot of participants working in secondary schools located in all Egypt should participate in the analysis process. However, covering all the areas cannot be accomplished in a short period of time.

3- The study was limited to female students; it could not be subjected to males as well 
because EFL instruction may be different from males to females.

4- The study was limited to Al-Azhar secondary school students; it could not be subjected to other Egyptian national secondary school students. The nature of studying EFL in Al Azhar has some different features that are different from other types of education.

5- The study was limited to secondary school students; it could not be subjected to all levels of school education according to the various thinking skills of each age and level.

\section{References}

Abdallah M. M. S., 2016. Issues with the 'Time for English' Textbook Series at Egyptian Primary Schools: An Evaluative Study. Journal of Faculty of Education, Assiut University, 32: 1(II), 2- 51.

Abdel-Monem H., 2019. A proposed communicative approach-based program to develop the English language skills of nonspecialist students. Unpublished thesis (M.A). Faculty of Education, Beni-Suef University.

Abuseif A., 2018. The effectiveness of the training program based on the positive thinking skills in reducing cognitive load among high school students. Unpublished thesis (M.A), Faculty of Education, Beni Sweif University.

Adesope O. O., 2010. The cognitive effects of verbal redundancy and animated concept maps on learning (Order No. NS23080). Available from
ProQuest Dissertations \& Theses Global. (1515803770). Retrieved from:

https://search.proquest.com/docview/1515803770? accountid $=178282$

Al Feel H. M., 2013. Designing e-course in psychology based on the principles of cognitive flixiblity theory and its effect on develping systems intelligence and reducing the cognitive load for faculty of specific education students, alexandria university. Unpublished thesis $(\mathrm{PhD})$, Faculty of Education, Alexandria University.

Alguthami R. A., 2016. Visual word recognition by arab ESL learners: Phonological versus orthographic consonantal influence on vowels (Order No. 10126988). Available from ProQuest Dissertations \& Theses Global. (1808939052). Retrieved from:

http://search.proquest.com/docview/1808939052? accountid $=178282$

Al-Morsi S. B., 2018. Suggested e-training program based on the cognitive load theory to develop the production of e-evaluation tools skills for computer teachers and their motivation for elearning. Unpublished thesis (M. A). Faculty of education, Cairo University.

Alshumaimeri Y. A., Alzyadi M. S., 2015. Using material authenticity in the saudi english textbook design: A content analysis from the viewpoint of EFL teachers. Advances in Language and Literary Studies, 6(2): 229-241. Retrieved from:

https://search.proquest.com/scholarlyjournals/using-material-authenticitysaudi.English/docview/2188090044/se 2? accountid $=178282$ 
Attar N., 2016. Enhancing cognitive load measurement and user performance in humancomputer interaction (Order No. 10194884). Available from ProQuest Dissertations \& Theses Global. (1868501493). Retrieved from:

https://search.proquest.comdocview1868501493ac countid=178282

Baddeley A., 2000. The episodic buffer: a new component of working memory? Trends in Cognitive Sciences, 4(11), 417-423.

doi: 10.1016/S1364-6613(00)01538-2

Baddeley A. D., 2000. Is working memory still working? American Psychologist, 56(11): 851864. doi:10.1037/0003-066X.56.11.851

Best E. E., 2013. Building schemata for tax provision learning based on cognitive load theory and constructivism (Order No. 3604653). Available from ProQuest Dissertations \& Theses Global. (1476439703). Retrieved from:

http://search.proquest.com/docview/1476439703? $\underline{\text { accountid }=178282}$

Bijani, C. (2015). Effects of input modality on capturing notes (Order No. 1602933). Available from ProQuest Dissertations \& Theses Global. (1729584983). Retrieved from:

http://search.proquest.com/docview/1729584983? accountid $=178282$

Boers F., Warren P., He L., Deconinck J., 2017. Does adding pictures to glosses enhance vocabulary uptake from reading?, In System, 66: 113-129, ISSN 0346-251X, https://doi.org/10.1016/j.system.2017.03.017.

Bui D. C., 2015. Using the encoding specificity principle to assess the nature of the secondary memory component of working memory (Order No. 3689333). Available from ProQuest Dissertations \& Theses Global. (1677222969). Retrieved from:

http://search.proquest.com/docview/1677222969? accountid $=178282$

Choi H., van Merriënboer J. G., Paas F., 2014. Effects of the physical environment on cognitive load and learning: Towards a new model of cognitive load. Educational Psychology Review, 26(2): 225-244. doi:10.1007/s10648-014-9262-6.

Dagry I., Vergauwe E., Barrouillet P., 2017. Cleaning working memory: The fate of distractors, In Journal of Memory and Language, 92, 327-342, ISSN 0749-596X,

https://doi.org/10.1016/j.jml.2016.08.002.

Dalacosta K., Kamariotaki M., Palyvos, J., Spyrellis M., 2009. Multimedia application with animated cartoons for teaching science in elementary education, Computers \& Education, 52(4): 741-748.

https://doi.org/10.1016/j.compedu.2008.11.018.

de Koning B. Rop G., Paas F., 2020. Effects of spatial distance on the effectiveness of mental and physical integration strategies in learning from split-attention examples, 110.Computers in Human Behavior, ISSN 0747-5632, https://doi.org/10.1016/j.chb.2020.106379. https://www.sciencedirect.com/science/article/pii/ $\underline{\text { S0747563220301321 }}$

Demanet J., Liefooghe B., Hartstra E., Wenke D., De Houwer J., Brass M. 2016. There is more into 'doing' than 'knowing': The function of the right inferior frontal sulcus is specific for implementing 
versus memorising verbal instructions, NeuroImage, 141: 350-356.

https://doi.org/10.1016/j.neuroimage.2016.07.059.

Diab O. M., 2013. Evaluation of 4th- 6th grades efl textbooks for their content creativity level. thesis (M.A), Brzeit University. Faculty of Education. Directions in Psychological Science, $15,265-268$.

Drobisz J., 2017. The effects of arousal presented by a pedagogical agent on English language learners' situational interest, cognitive load and reading comprehension in online reading tasks (Order No. 10256680). Available from ProQuest Dissertations \& Theses Global. (1895549630). Retrieved from:

https://search.proquest.com/docview/1895549630? accountid $=178282$

El-Sayed A., 2015. Evaluating English for commercial school series textbook in the light of proposed ESP criteria. Thesis (M.A), Faculty of Education, Mansoura University.

Grobe C., 2018. Copying allowed - But be careful, errors included!" - Effects of copying correct and incorrect solutions on learning outcomes, Learning and Instruction, 58: 173-181. https://doi.org/10.1016/j.learninstruc.2018.06.004

Gupta U. 2017. Managing cognitive load during complex learning A study on worked examples and element interactivity (Order No. 10273022). Available from ProQuest Dissertations \& Theses Global. (1903600005). Retrieved from:

https://search.proquest.comdocview1903600005ac countid $=178282$
Hart Sandra G., Staveland Lowell E., 1988. "Development of NASA-TLX (Task Load Index): Results of Empirical and Theoretical Research" . doi:10.1016/S0166-4115(08)623869. ISBN 978-0-444-70388-0.

Jankowska Gierus B., 2011. Learning with visual representations through cognitive load theory (Order No. MR83974). Available from ProQuest Dissertations \& Theses Global. (1033341737). Retrieved from:

http://search.proquest.com/docview/1033341737? accountid $=178282$

Jiang X., 2014. Vocabulary learning through use of the picture-word inductive model for young English learners in china: A mixed methods examination using cognitive load theory (Order No. 3644776). Available from ProQuest Dissertations \& Theses Global. (1637726677). Retrieved from:

http://search.proquest.com/docview/1637726677? accountid $=178282$

Joh J., Plakans L., 2017. Working memory in L2 reading comprehension: The influence of prior knowledge, In System, 70: 107-120.

https://doi.org/10.1016/j.system.2017.07.007.

Johnson H., 2012. The effect of a high school speech course on public speaking anxiety for students in a college-level public speaking class (Order No. 3519055). Available from ProQuest Dissertations \& Theses Global. (1036631294). Retrieved from:

https://search.proquest.com/docview/1036631294? accountid $=178282$ 
Lin H., Chen T., 2006. Decreasing cognitive load for novice EFL learners: Effects of question and descriptive advance organizers in facilitating EFL learners' comprehension of an animation-based content lesson, 34, (3), 416-43. System. ISSN 0346-251X,

https://doi.org/10.1016/j.system.2006.04.008. https://www.sciencedirect.com/science/article/pii/ $\underline{\mathrm{S} 0346251 \mathrm{X} 06000595}$

Mokhtar H., Farida A., Kamarulzaman Z., 2011. The Effectiveness of Storytelling in Enancing Communicative Skills, In Procedia - Social and Behavioral Sciences, 18: 163-169.

https://doi.org/10.1016/j.sbspro.2011.05.024.

Namaziandost E., Hosseini E., Utomo D. W., 2020. A comparative effect of high involvement load versus lack of involvement load on vocabulary learning among iranian sophomore EFL learners. Cogent Arts \& Humanities, 7(1) http://dx.doi.org/10.1080/23311983.2020.1715525

Presbitero A., 2020. Foreign language skill, anxiety, cultural intelligence and individual task performance in global virtual teams: A cognitive perspective, 26:(2), Journal of International Management, ISSN:1075-425.

https://doi.org/10.1016/j.intman.2019.100729. https://www.sciencedirect.com/science/article/pii/ $\underline{\text { S1075425319300833 }}$

Rahmawati L., 2018. A content analysis of the English textbook, primary English as a second language. Thesis (PhD). Faculty of Education and Teacher Training, Sunan Ampel State Islamic University.
Roohani A., Sharifi M., 2015. Evaluating visual elements in two EFL textbooks. 4:(2): 68-77 68 Indonesian Journal of Applied Linguistics.

Russell A., 2011. A cognitive load approach to learner-centered design of digital instructional media and supporting accessibility tools (Order No. 1500419). Available from ProQuest Dissertations \& Theses Global. (899692322).

Retrieved from:

https://search.proquest.com/docview/899692322?a $\underline{\text { ccountid }=178282}$

Sándorová Z., 2019. Content analysis as a research method in investigating the cultural components in foreign language textbooks. Journal of Language and Cultural Education.

https://www.researchgate.net/publication/3311142 $\underline{59}$

Sentz J. A., 2018. Instructional designer awareness and application of strategies to manage cognitive load (Order No. 10788024). Available from ProQuest Dissertations \& Theses Global. (2038374200). Retrieved from:

https://search.proquest.com/docview/2038374200? $\underline{\text { accountid }=178282}$

Sexton T., 2017. Exploring the influence of students' perceptions of instructional message content relevance and experienced cognitive load on students' cognitive learning (Order No. 10628874). Available from ProQuest Dissertations \& Theses Global. (1920422201). Retrieved from: http://search.proquest.com/docview/1920422201? accountid $=178282$ 
Shehab M., 2011. Cognitive load of critical thinking strategies (Order No. 3460898). Available from ProQuest Dissertations \& Theses Global. (879043018). Retrieved from:

https://search.proquest.com/docview/879043018?a ccountid $=178282$

Songdan N. G., Feng D., 2015. Infusing multiliteracies into English language curriculum: The visual construction of knowledge in English textbooks from an ontogenetic perspective, Linguistics and Education, 31: 115-129.

https://doi.org/10.1016/j.linged.2015.07.001.

Sterci N., 2016. Communicative solutions through technology: An evaluation of ESL textbooks in brazil (Order No. 10246706). Available from ProQuest Dissertations \& Theses Global. (1864695205). Retrieved from:

http://search.proquest.com/docview/1864695205? accountid $=178282$

Sweller J., Yeung S., Jin P., 1998. Cognitive Load and Learner Expertise: Split-Attention and Redundancy Effects in Reading with Explanatory Notes, In Contemporary Educational Psychology, 23(1): 1-21.

\section{https://doi.org/10.1006/ceps.1997.0951.}

Sweller J., 1994. Cognitive load theory, learning difficulty, and instructional design, In Learning and Instruction, 4(4): 295-312.

https://doi.org/10.1016/0959-4752(94)90003-5
Sweller J., Wong A., Leahy W., Marcus N., 2012. Cognitive load theory, the transient information effect and e-learning, In Learning and Instruction, 22(6): 449-457.

https://doi.org/10.1016/j.learninstruc. 05.004.

Sweller L., Ayres P., Kalyuga S., 2011. Explorations in the Learning Sciences, Instructional Systems and Performance Technologies.

https://doi.org/10.1007/978-1-4419-8126-4

Teng F., 2015. Involvement load in translation tasks and EFL vocabulary learning. The New English Teacher, 9(1). Retrieved from: https://search.proquest.com/scholarlyjournals/involvement-load-translation-tasks-eflvocabulary/docview/2384114184/se-

2? accountid $=178282$

Wirth J., Künsting J., Leutner D., 2009. The impact of goal specificity and goal type on learning outcome and cognitive load, Computers in Human Behavior, 25(2): 299-305.

https://doi.org/10.1016/j.chb.2008.12.004.

Woolley K., Huang T., Rabinowitz M., 2019. The effects of knowledge, strategies, and the interaction between the two in verbal analogy problem solving, Contemporary Educational Psychology, 56: 91-105. https://doi.org/10.1016/j.cedpsych.2018.12.003. 